Pak. j. sci. ind. res. Ser. B: biol. sci. 2021 64B(3) 217-224

\title{
Habitat Types Effect on Diversity, Distribution and Abundance of Dung Beetles
}

\author{
Nadia Noureen ${ }^{\mathrm{a}}$, Mubashar Hussain ${ }^{\mathrm{b} *}$, Muhammad Faheem Malik ${ }^{\mathrm{b}}$, Muhammad Umar \\ Zaheer Abbas ${ }^{c}$ and Saira Munawar ${ }^{d}$ \\ ${ }^{a}$ Department of Zoology, Govt. Sadiq College Women University, Bahawalpur, Pakistan \\ ${ }^{\mathrm{b}}$ Department of Zoology, University of Gujrat, Pakistan \\ ${ }^{\mathrm{c}}$ Department of Statistics, University of Gujrat, Pakistan \\ ${ }^{\mathrm{d}}$ Department of Geography, University of Gujrat, Pakistan
}

(received September 13, 2018; revised January 01, 2019; accepted January 08, 2019)

\begin{abstract}
Dung beetles are ecologically important taxa to study the assessment of habitat modification and disturbance across the globe. This study was aimed to explore community composition, species richness and abundance of dung beetles in response to Gujrat, Punjab, Pakistan. Dung beetle assemblage were sampled from four habitat (natural rangeland, cropland, roadside and housing colonies) during 2014-2016 by placing pitfall traps baited with cattle dung. A total number of 540 specimens representing 17 species belonging to seven genera and four tribes were collected. We calculated species relative abundance in natural habitat $(34.8 \%)$, cropland habitat $(40.4 \%)$ and in road side areas $(25.2 \%)$ was recorded, whereas no specimens were recorded in urban areas. Aphodius contaminatus $(42.96 \%)$ was the most abundant species followed by Onitis castaneous (26.29\%) and Onitis singhalensis (20.74\%). Tunnellers (50.58\%) and dwellers (49.01\%) were dominant in all habitats, whereas rollers were least abundant (1.37\%). The values of Shannon-Wiener $(\mathrm{H})$ diversity and evenness $(\mathrm{E})$ showed variations among different habitats i.e. natural habitat $(\mathrm{H}=1.20 ; \mathrm{E}=0.55)$, cropland habitat $(\mathrm{H}=1.41, \mathrm{E}=0.32)$ and roads-side $(\mathrm{H}=0.80, \mathrm{E}=0.37)$. The study showed that cropland served as a major habitat for dung beetles due to its uniformity and close association with mammalian fauna. The results emphasized that natural habitats within the agro-ecosystem have become isolated and fragmented habitat with lesser stability and low resources thus resulting into less diverse habitat. Roadside areas are in close proximity with cropland and act as corridors for efficient species flow within ecosystem due to cattle movement through these areas.
\end{abstract}

Keywords: habitat, scarabaeidae, dung beetles, Pakistan

\section{Introduction}

Human interventions have caused a higher degree of heterogeneity in agricultural landscape at both spatial and temporal scale and largely affected the species that inhabit these lands (Macdonald and Smith, 1990). Anthropogenic settlements change the plantation structure to monocultures directly or indirectly altering characters of a habitat. Such conditions abolish the establishment of preexisting species in new environment. These physical changes result in habitat loss by converting it into smaller plots of land (Collins et al., 2000; Medley et al., 1995) leading to more urban gradient.

Natural landscapes have gradually transformed into agro ecosystem, sub urban and finally urban areas resulting a frequent loss in natural habitat within a few decades all over the world (Davis, 1979). Urbanization

*Author for correspondence;

E-mail: dr.mubashar@uog.edu.pk results in the decline of biodiversity at a greater rate (Davis, 1979). Species diversity and abundance becomes limited specifically at the urban edges. Urban landscape either eliminates the endemic species completely from its natural habitat by limiting the resources or it may also provide a widespread area for a certain species to flourish (Ott, 1995). Habitat modifications accelerated by humans are going to be expediting in future, hence, leading to more rapid loss of biodiversity. It is essential to assess the sensitivity and response of biotic communities to habitat change for predicting biodiversity loss and designing and proposing conservatory efforts (Sala et al., 2000).

Insect population is directly or indirectly affected primarily due to change in habitat as they respond to the change in microclimatic conditions resulting in the modification in the community composition (Gerstmeicr and Lang, 1996; Curry, 1994; Fewkes, 1961; Franz, 1931). Urbanization affects insect population by reduced availability of land due to industrialization and housing, 
environmental pollution (Hafernik, 1992; Davis, 1979) and by isolating the microhabitats (Kindrall and Ahlen, 1992).

Dung beetles are efficient decomposers and play a vital role in nutrient recycling, soil turnover, seed dispersal and as parasitoids of several flies (Nichols et al., 2008; Andresen and Levey, 2004; Andersen, 2002a, 2002b, 1999; Horgan, 2001; Halffter and Matthews, 1966). This group acts as an indicator of habitat disintegration, disturbance and diversity richness in tropical forests (Nichols et al., 2007; Spector, 2006; Halffter and Arellano, 2002) because these are strongly associated with the mammalian fauna of ecosystem (Spector, 2006).

Differences in locality and habitat conditions give rise to a different type of community composition of dung beetles. Diversity of dung beetles is greater in forest as compared to grassland (Edwards et al., 2017; Frank et al., 2017). They respond negatively to habitat changes, fragmentation and isolation of forest patches and intensive land use (Shahabuddin et al., 2010; Gardner et al., 2008; Nichols et al., 2007; Halffter et al., 1992) but the effect of urbanization is still not very clear (Radtke et al., 2008; Carpaneto et al., 2005; Wallace and Richardson, 2005).

The present study was conducted to evaluate the impact of habitat change on dung beetle diversity due to urbanization in an agricultural area in semi-arid regions of Pakistan where intensive industrialization and massive constructions have altered the natural habitats of insect fauna. The impact of habitat loss on dung beetles is necessary to understand in order to have an insight into bio-indication, decomposition activities and to design a conservation strategy for dung beetles. This study was designed to evaluate community structure of dung beetles in four different habitats and to assess their response towards habitat disturbance.

\section{Material and Methods}

Experimental details and sampling. Study area. The study was conducted in the vicinity of Gujrat city during July 2014 - June 2016 representing different habitats with variable human intervention. The sampling units are located at the northern boundary of Punjab province between latitude $32.57,38^{\circ} \mathrm{N}$ and longitude $74.07,89$ ${ }^{\circ} \mathrm{E}, 224$ meters above the sea level. The Punjab province is fed by five major rivers and comprises an agrarian economy province of Pakistan.
The study area has two major rivers, the river Chenab and the river Jhelum making the area suitable for agricultural activities. The maximum temperature is 45 ${ }^{\circ} \mathrm{C}$ during summers that does not prolong due to the proximity of mountains of Azad Kashmir and below 2 ${ }^{\circ} \mathrm{C}$ during the winter season. On the basis of crops produced, Gujrat is divided into two categories, irrigated and rain-fed regions. Overall the climate of Gujrat is moderate and the soil is suitable for cultivation of a variety of crops. But massive increase in population and the establishment of vast industrial units have replaced the croplands.

The study area was divided into four main sites; natural habitat comprised of undisturbed semi-forest area (rangeland), croplands with seasonal crops, roads and construction sites, and the urban area including gardens and lawns in housing colonies (Fig. 1).

A preliminary survey was conducted to locate the appropriate sampling sites in these areas. Each of the sites was further sub-divided into five sampling units as described in Table 1.

Sampling. Pitfall traps baited with cattle dung were used for sampling. A total of 12 traps were placed fortnightly during the whole study period. Five traps per sampling site were placed with a distance of $10 \mathrm{~m}$ in a square with the fifth trap in the center of the square

Table 1. Description of sampling sites in Gujrat, Punjab, Pakistan

\begin{tabular}{ll}
\hline \hline Habitat type & Habitat description \\
\hline $\begin{array}{l}\text { Natural habitat } \\
\text { (NH 1-5) }\end{array}$ & $\begin{array}{l}\text { Natural habitat comprised of semi forest } \\
\text { area, about 20 km away from Gujrat city } \\
\text { in the north. Five sampling units were } \\
\text { selected and named after the surrounding } \\
\text { villages as Kakrali, Sabor, Miana Chak, } \\
\text { Dolat Nagar and Rehmania Pul }\end{array}$ \\
Cropland & $\begin{array}{l}\text { Cropland habitats were selected as Ikhlas } \\
\text { Garh, Ghuman, Kotli Kohala, Sook Kalan } \\
\text { and Mangowal. Crops and the adjacent }\end{array}$ \\
Road side area & $\begin{array}{l}\text { Five roads surrounding Gujrat city were } \\
\text { sampled as, Bhimber road, Jalal pur Jattan }\end{array}$ \\
& $\begin{array}{l}\text { to Kharian road, University-Gandra road } \\
\text { and Kunjah road }\end{array}$ \\
Housing colonies & $\begin{array}{l}\text { Housing colonies named as Model town, } \\
\text { Shalimar town, Service More, Haryawala }\end{array}$ \\
& $\begin{array}{l}\text { Chowk and Shaheen Chowk in Gujrat } \\
\text { city were selected and gardens and lawns } \\
\text { of houses were taken as sampling units }\end{array}$ \\
\hline \hline
\end{tabular}




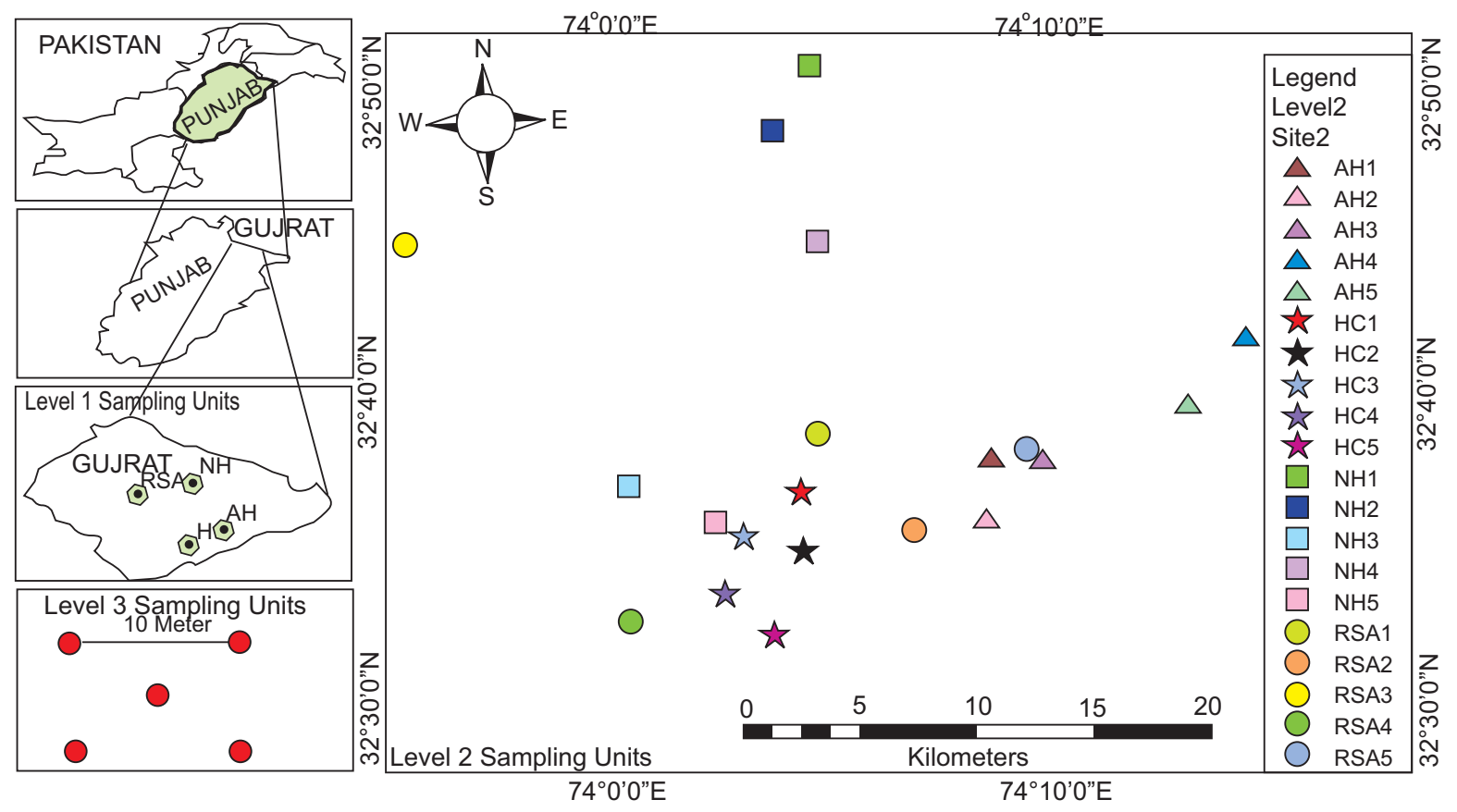

Fig. 1. Map of sampling sites in Gujrat, Punjab, Pakistan.

(Fig. 1). Pitfall traps consisted of $200 \mathrm{~mL}$ transparent plastic cups with a diameter of $8 \mathrm{~cm}$ containing $50 \mathrm{~mL}$ salt water mixed with detergent to reduce surface tension (Larsen and Forsyth, 2005). The traps were placed in the soil, while their rims were in the level with the soil surface. Traps were covered with plastic net with three holes of suitable size and $10 \mathrm{~g}$ fresh cattle dung wrapped in a plastic bag was placed on it.

Data collection. Beetles were collected after every 4 $\mathrm{d}$ and dung was refreshed as it loses its attractiveness after $48 \mathrm{~h}$. Collected specimens were immediately shifted to killing jars which were made by using KCN. The specimens were preserved in $70 \%$ alcohol and then identified to the species level by examining through a binocular microscope and using identification keys by Balthasar (1963) and Arrow (1931) then tagged. Specimens were then divided into their functional guild comprising of tunnelers, dwellers and rollers to evaluate their functional and spatial guild composition. All the collected species were then dry pinned in wooden collection boxes containing naphthalene tablets to avoid fungal attacks and deposited to the zoological museum in the Department of Zoology, University of Gujrat.

Data analysis. Species accumulation curves and species richness estimators were estimated by EstimateS. Diversity (Magurran, 2004) was estimated using Shannon-Weaver diversity index (Shannon and Weaver,
1949), evenness with Simpson's evenness index (Simpson, 1949), richness with Margalef's species richness index (d) and Berger-Parker index for species dominance. Analysis of variance for differences in habitats, sites and species was performed by three-way ANOVA test.

\section{Results and Discussion}

Species composition. A total number of 540 specimens were collected during a two-year study period (July, 2014 - June, 2016). From the 300 baited traps, a total of 186, 218 and 136 individuals were captured from natural forest, cropland and road sides, respectively (Table 2). It represented 17 species belonging to seven genera and four tribes. The percentage composition of species abundance in natural habitat $(34.8 \%)$, cropland habitat $(40.4 \%)$ and in road side areas $(25.2 \%)$, whereas no specimens were recorded in urban areas.

The data indicated that three species were most common, two common, three less common and 8 were least common. Maximum number of species belonged to Scarabeinae representing the genera, Catharsius (5 species), Onitis (6 species), Heliocopris (1 species), Onthophagus (1 species) and Gymnopleurus (2 species) and there species belonged to family Aphodiinae named as $A$. contaminatus, $A$. fossor and $O$. cinctus (Oniticellini). Among three major species $A$. contaminatus 
(Aphodiinae) dominated the cropland while $O$. castaneous and $O$. singhalensis (Scarabaeinae) showed a higher abundance in natural habitat but were also common in agricultural habitat.

The abundance data collected by natural habitat revealed that six species named $A$. contaminatus, $O$. castaneous, $O$. singhalensis, $C$. molessus, $H$. bucephalus and $O$. cinctus were found in the habitat with variable numbers significantly different from each other. In cropland habitat, 13 species were captured showing different abundance and represented by the $A$. contaminatus, $O$. castaneous, $O$. singhalensis, $O$. cinctus, $O$. excavatus, A. fossor, G. bicallosus, O. subopacus, O. philemon, $O$. falcatus, $C$. granulates, $C$. pithecius and $O$. gazella. The data from roadside habitat revealed the presence of six species with an abundance of $A$. contaminatus, O. castaneous, $O$. singhalensis, $O$. excavatus, C. platypus and C. sagax.

Functional guild. The captured species were differentiated into their functional guild. Out of seventeen species collected, thirteen species were Paracoprid (Tunnelers), three were Endocoprid (Dwellers) and one species belonged to Telocoprid (Rollers) guild (Table 2).

Tunnelers were the dominant group representing a species composition of about $50 \%$ and were found in three habitats (natural habitat, cropland and roadside areas). Dwellers shared about $48 \%$ of the total abundance inhabited under natural habitat and cropland, whereas only one species was found in the road-side area and it was collected from all three habitats. However, Rollers were the rare guild comprising only $1.4 \%$ of the total reported species and were collected from the cropland only. Large-sized individuals were found in natural habitat, whereas small-sized were common with the large-sized specimens in cropland and roadside habitats.

Species richness and abundance. Species richness was expressed in terms of Shannon-Weiner diversity index for the three habitats natural, cropland and roadside areas where different species were captured. There were no species reported from housing colonies. However, the dung beetle species were collected from village-based residential areas characterized by the presence of cattle. Diversity and evenness values were calculated for natural habitat $(\mathrm{H}=1.20 ; \mathrm{E}=0.55)$, cropland habitat $(\mathrm{H}=1.41, \mathrm{E}=0.32)$ and roads-side $(\mathrm{H}=0.80$, $\mathrm{E}=0.37$ ).

Simpson's index for natural, cropland and road-side area was $0.64,0.65$ and 0.40 , respectively. Margalef's richness index was 0.96 for natural habitat, 2.23 for cropland habitat and 1.02 for roadside habitat. The

Table 2. Habitat-wise relative abundance of species captured from Gujrat, Punjab, Pakistan during 2014-2016

\begin{tabular}{|c|c|c|c|c|c|c|c|}
\hline \multirow[t]{2}{*}{ Species name } & \multirow{2}{*}{$\begin{array}{l}\text { Functional } \\
\text { guild }\end{array}$} & \multicolumn{4}{|c|}{ Habitat-wise abundance (\%) } & \multirow{2}{*}{$\begin{array}{l}\text { Species } \\
\text { abundance } \\
\text { (no.) }\end{array}$} & \multirow{2}{*}{$\begin{array}{l}\text { Relative } \\
\text { abundance } \\
(\%)\end{array}$} \\
\hline & & $\begin{array}{l}\text { Natural } \\
\text { habitats }\end{array}$ & Croplands & $\begin{array}{l}\text { Road side } \\
\text { areas }\end{array}$ & $\begin{array}{l}\text { Housing } \\
\text { colonies }\end{array}$ & & \\
\hline $\begin{array}{l}\text { Aphodius } \\
\text { contaminatus }\end{array}$ & Dwellers & 6.034483 & 49.56897 & 44.39655 & 0 & 232 & 45.49 \\
\hline Onitis castaneous & Tunnelers & 46.47887 & 38.02817 & 15.49296 & 0 & 142 & 23.92 \\
\hline Onitis singhalensis & Tunnelers & 78.57143 & 19.64286 & 1.785714 & 0 & 112 & 20.00 \\
\hline Oniticellus cinctus & Dwellers & 78.94737 & 21.05263 & 0 & 0 & 19 & 3.72 \\
\hline Onitis excavatus & Tunnelers & 0 & 57.14286 & 42.85714 & 0 & 14 & 2.74 \\
\hline Aphodius fossor & Dwellers & 0 & 100 & 0 & 0 & 7 & 1.37 \\
\hline Catharsius molessus & Tunnelers & 100 & 0 & 0 & 0 & 2 & 0.392 \\
\hline Catharsius platypus & Tunnelers & 0 & 0 & 100 & 0 & 2 & 0.392 \\
\hline $\begin{array}{l}\text { Gymnopleurus } \\
\text { bicallosus }\end{array}$ & Rollers & 0 & 100 & 0 & 0 & 2 & 0.392 \\
\hline Onitis philemon & Tunnelers & 0 & 100 & 0 & 0 & 1 & 0.196 \\
\hline Onitis subopacus & Tunnelers & 0 & 100 & 0 & 0 & 1 & 0.196 \\
\hline Onitis falcatus & Tunnelers & 0 & 100 & 0 & 0 & 1 & 0.196 \\
\hline Catharsius sagax & Tunnelers & 0 & 0 & 100 & 0 & 1 & 0.196 \\
\hline $\begin{array}{l}\text { Catharsius } \\
\text { granulatus }\end{array}$ & Tunnelers & 0 & 100 & 0 & 0 & 1 & 0.196 \\
\hline $\begin{array}{l}\text { Heliocopris } \\
\text { bucephalus }\end{array}$ & Tunnelers & 100 & 0 & 0 & 0 & 1 & 0.196 \\
\hline Catharsius pithecius & Tunnelers & 0 & 100 & 0 & 0 & 1 & 0.196 \\
\hline Onthophagus gazella & Tunnelers & 0 & 100 & 0 & 0 & 1 & 0.196 \\
\hline
\end{tabular}


results demonstrated higher species richness in cropland habitat. Berger-Parker index for species dominance was 0.47 for natural, 0.53 for croplands and 0.76 for roadside habitat. Indices showed that cropland area was more diverse than the other two habitats (Table 3).

The statistical analysis of the data showed significant results for species abundance in all habitats (Table 4). The species accumulation curve calculated by EstimateS was asymptote showing the tendency towards more coverage of species in selected study area (Fig. 2). Species richness estimators including Mao tau, Chao 1 and 2, Abundance-based Coverage Estimator and Incidence-based Coverage Estimator were plotted. Chao 1 and Chao 2 were steeper, indicating the presence of more unique and doubletons species in the data while ACE was climbing gradually with a diverse trend of abundance (Fig. 3).

The study was designed to explore the effect of habitat modification on dung beetle. Diversity indices including Shannon-Weiner index, Simpson's index, Margalef's species richness index and Berger-Parker dominance index revealed that the species richness was not significantly different in each habitat. But data indicated variation in the abundance of different habitats. Cropland

Table 3. Species diversity indices calculated for different type of habitats of Gujrat, Punjab, Pakistan

\begin{tabular}{llll}
\hline \hline Indices & $\begin{array}{l}\text { Natural } \\
\text { habitat }\end{array}$ & Croplands & $\begin{array}{l}\text { Road side } \\
\text { areas }\end{array}$ \\
\hline Taxa_S & 6 & 13 & 6 \\
Individuals186 & 218 & 136 & \\
Dominance_D & 0.3621 & 0.3527 & 0.6022 \\
Simpson_1-D & 0.6379 & 0.6473 & 0.3978 \\
Shannon_H1. & 196 & 1.411 & 0.8031 \\
Evenness_e^H/S & 0.5513 & 0.3153 & 0.3721 \\
Margalef & 0.9568 & 2.229 & 1.018 \\
Berger-Parker & 0.4731 & 0.5275 & 0.7574 \\
\hline \hline
\end{tabular}

Table 4. Species diversity indices calculated for different type of habitats of Gujrat, Punjab, Pakistan

\begin{tabular}{llllll}
\hline \hline Source & $\begin{array}{l}\text { Type III sum } \\
\text { of squares }\end{array}$ & Df & Mean square & F & Significance \\
\hline Model & $488 \mathrm{a}$ & 23 & 21.2 & 109 & 0 \\
Habitat & 3.36 & 2 & 1.67 & 8.59 & 0 \\
Sites & 0.48 & 4 & 0.12 & 0.62 & 0.65 \\
Species & 389 & 16 & 24.3 & 125 & 0 \\
Error & 592 & 3037 & 0.19 & & \\
Total & 1080 & 3060 & & & \\
\hline \hline
\end{tabular}

a. $\mathrm{R}$ squared $=.45($ Adjusted $\mathrm{R}$ squared $=.45)$

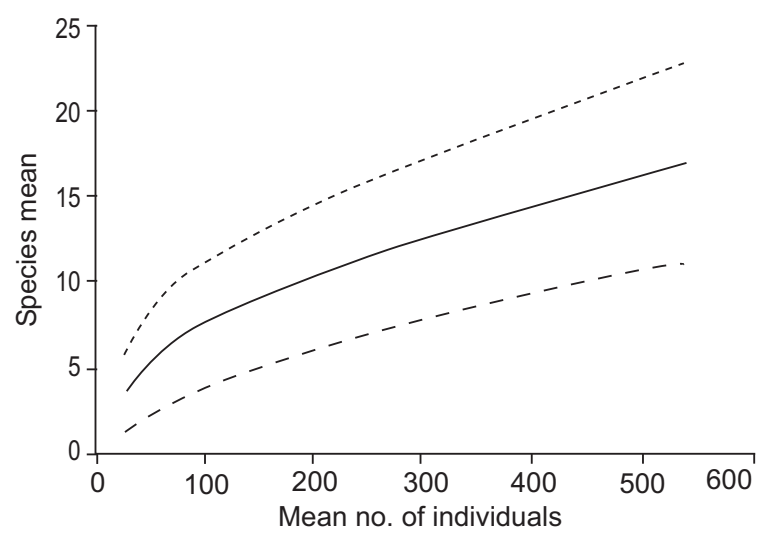

Fig 2. Asymptote species accumulation curve (Sobs Mau-Tau) based on the number of individuals at $95 \%$ confidence level.

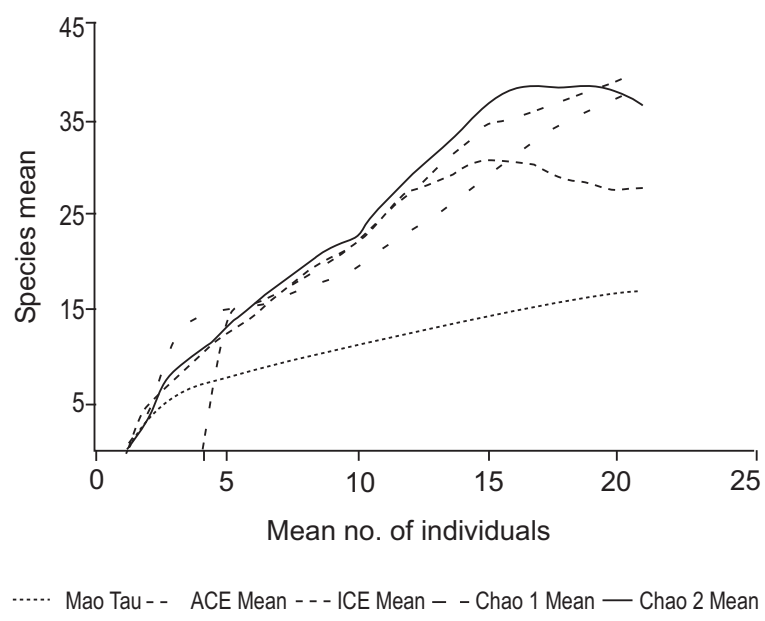

Fig 3. Species richness estimates, species richness estimators including Mao tau, Chao 1 and 2, Abundance-based coverage estimator and incidence-based coverage estimator.

habitat showed maximum abundance. Magurran (2004) reported that abundance was independent of species richness that is similar to our work.

Maximum species diversity was observed in cropland habitat and no species was found in the housing colonies. These results were quite opposite to the expectations. In most studies natural habitats were observed with maximum number of species (Estrada and CoatesEstrada, 2002). Natural habitats are least disturbed habitats but anthropogenic activities have transformed them into disturbed isolated patches. 
The land use change of natural habitat has resulted in a stable agro-ecosystem. Cropland has emerged as a dominant habitat in cultivated area. Janzen (1983) reported that forest has become more fragmented and disturbed but urbanized habitat are more stable, dominant and old in terms of species composition. Similar, observations were recorded in other regions (Gardner et al., 2008; Larsen et al., 2005; Scheffler, 2005; Vulinec, 2002; Klein, 1989).

It revealed that urbanization changed the species composition in all habitats. Community structure changes with change in habitat. Hill (1996) reported that changes in dung beetle assemblage structure occur over tens of meters. In our study the distances between sampling units were 10-12 Km. Scarabaeinae was most abundant in all habitats with Aphodius dominating cropland and roadside habitats. Spector and Ayzama (2003) reported variation in species structure for just a few meter distances.

Species dominance varied from one habitat to another. $A$. contaminatus was dominant in cropland and roadside habitat. In natural habitat $O$. singhalensis and $O$. castaneous were the dominant species, but also frequently found in cropland and roadside habitats. The community structure varied from abundant to rare species in all habitats. Dung beetle abundance is characterized by the availability of the resources in a habitat (Horgan, 2005).

The dung beetle assemblage and colonization patterns are generally observed as a few dominant, some common and a large number of rare species due to temporary nature of resources in a habitat (Doube, 1983). The results indicated a greater number of rare and unique species (Hanski and Cambefort, 2014).

Species evenness revealed a gradient of disturbance as this value was greater in natural habitat and lesser in cropland and roadside habitat. Evenness is inversely proportional to species diversity and dominance. The greater values of evenness indicate the greater dominance and species diversity.

Guild structure exhibited dominance of tunnelers over dwellers and rollers in natural habitat. This type of dominance is a typical assemblage of dung beetles reported from different regions of the world (Sabu et al., 2007, 2006; Vinod and Sabu, 2007; Andresen, 2005; Cambefort and Walter, 1991). Dwellers dominated the cropland and roadside habitat. Similar results were reported by Vinod (2009) due to greater availability of dung pat. It has been observed that dominance of dwellers in croplands with little mammalian diversity replaces other guilds i.e., Tunnelers and rollers. The presence of both large- and small-sized individuals revealed the stability of habitats especially croplands which has emerged as successful man-managed habitats. Dung beetles have adapted to these monocultures fragmented agricultural belts as a safe micro-habitat. The study revealed the diversity and distribution pattern of the basic fauna of dung beetles in the selected areas and behavioural changes exhibited by the said species with the degree of change in habitat and the interactions of dung beetles within and between species and with other components of ecosystem. It has also assessed the potential of dung beetle to resist and respond to habitat modification. It was concluded that cropland has been developed as a safe and stable man-managed habitat. Agro-ecosystem supports species diversity and richness more than isolated fragmented natural habitats due to uniform vegetation and managed faunistic patterns. In addition to this, roadside habitats act as corridors for species flow within agricultural area and also well adapted to dung beetles due to availability of resources.

Conflict of Interest. The authors declare no conflict of interest.

\section{References}

Andresen, E. 2005. Effects of season and vegetation type on community organization of dung beetles in a tropical dry forest. Biotropica, 37: 291-300.

Andresen, E., Levey, D. 2004. Effects of dung and seed on secondary dispersal, seed predation and seedling establishment of rain forest trees. Oecologia, 139: 45-54.

Andresen, E. 2002a. Primary seed dispersal by red howler monkeys and the effect of defecation patterns on the fate of dispersed seeds. Biotropica, 34: 261272.

Andresen, A. 2002b. Dung beetles in a central Amazonian rain forest and their ecological role as secondary seed dispersers. Ecological Entomology, 27: 257-270.

Andresen, E. 1999. Seed dispersal by monkeys and the fate of dispersed seeds in a Peruvian rain forest. Biotropica, 31: 145-158.

Arrow, G.J. 1931. The Fauna of British India Including Ceylon and Burma, p. 428, Col. Lamella III (Coprinae), Taylor and Francis, London, UK. 
Balthasar, V. 1963. Monographie der Scarabaeidae und Aphodiidae der Palaearktischen und Orientalischen Region, Prague.

Cambefort, Y., Walter, P. 1991. Dung beetles in Tropical Forests in Africa. In: Dung Beetle Ecology, Hanski, I., Cambefort, Y., (eds.), pp. 198-210. Princeton University Press. Princeton, New Jersey, USA.

Carpaneto, G.M., Mazziotta, A., Piattela, E. 2005. Changes in food resources and conservation of scarab beetles, from sheep to dog dung in a green urban area old Rome (Coleoptera: Scarabaeoidea). Biological Conservation, 123: 547-556.

Collins, J.P., Kinzig, A., Grimm, N.B., Fagan, W.F., Hope, D., Wu, J., Borer, E.T. 2000. A new urban ecology. American Scientist, 88: 416-425.

Curry, J.P., 1994. Grassland Invertebrates, Leledn. Publisher Chapman \& Hall, London, UK.

Davis, B.N.K. 1979. The ground arthropods of London gardens. LortdortNcrr, 58: 15-24.

Doube, B.M. 1983. The habitat preference of some bovine dung beetles (Coleoptera: Scarabaeidae) in Hluhluwe game reserve, South Africa. Bulletin of Entomological Research, 73: 357-371.

Edwards, F.A., Finan, J., Graham, L.K., Larsen, T.H., Wilcove, D.S., Hsu, W.W., Hamer, K.C. 2017. The impact of logging roads on dung beetle assemblages in a tropical rainforest reserve. Biological Conservation, 205: 85-92.

Estrada, A., Coates-Estrada, R. 2002. Dung beetles in continuous forest, forest fragments and in an agricultural mosaic habitat island at Los Tuxtlas Mexico. Biodiversity Conservation, 11: 1903-1918.

Fewkes, D.W. 1961. Diel vertical movements in some grassland Nabidae (Heteroptera). Entomology Monthly Magazine, 97: 28-130.

Frank, K., Hülsmann, M., Assmann, T., Schmitt, T., Blüthgen, N. 2017. Land use affects dung beetle communities and their ecosystem service in forests and grasslands. Agriculture, Ecosystems and Environment, 243: 114-122.

Franz, I.T. 1931. Über die bedeutung des mikroklimasfür die faunenzusammensetzung auf kleinemRaum. Zeits Morphol Ökol Tier, 22: 587-628.

Gardner, T.A., Barlow, J., Araujo, I.S., Avila-Pires, T.C., Bonaldo, A.B., Costa, J.E., Esposito, M.C., Ferreira, L.V., Hawes, J., Hernandez, M.I.M., Hoogmoed, M.S., Leite, R.N., Loman-Hung, N.F., Malcolm, J.R., Martins, M.B., Mestre, A.L., Miranda-Santos, R., Oeral, W.L., Parry, L., Peters, S.L., Ribeiro, M.A., Da silva, M.N.F., Motta C.D.S., Peres, C.A.
2008. The cost-effectiveness of biodiversity surveys in tropical forests. Ecology Letters, 11: 139-150.

Gardner, T.A., Hernandez, M.I.M., Barlow, J., Peres, C.A. 2008. Understanding the biodiversity consequences of habitat change, the value of secondary and plantation forests for neotropical dung beetles. Journal of Applied Ecology, 45: 883 893.

Gerstmeicr, R., Lang, C. 1996. Beitragzu Auswirkungen der Mahd auf Arthropoden. Zeits. Ökolo. Naturschutz, 5: 1-14.

Hafernik, J.E. 1992. Threats to invertebrate diversity, implications for conservation strategies. In: Consert $\sim$ crrio Btiology:TheTlteor) ! ut 7 dtlte Procrice of Ncrture Conservurio17Presert crrion und Mcrncrgemenr, Fiedler, P.L. and Jain, S.K. (ed.), p. 171-195, Chapman and Hall, London, UK.

Halffter, G., Arellano, L. 2002. Response of dung beetle diversity to human-induced changes in a tropical landscape. Biotropica, 34: 144-154.

Halffter, G., Favila, M.E., Halffter, V. 1992. A comparative study of the structure of the scarab guild in Mexican tropical rain forest and derived ecosystems. Folia Entomolégica Mexicana, 84: 131-156.

Halffter, G., Matthews, E.G. 1966. The natural history of dung beetles of the sub family Scarabaeinae (Coleoptera: Scarabaeidae). Folia Entomolégica Mexicana, 12: 1-312.

Hanski, I., Cambefort, Y. 2014. Dung Beetle Ecology, 1195, pp. 305-329, Princeton University Press, New Jersey, USA.

Hill, C.J. 1996. Habitat specificity and food preferences of an assemblage of tropical Australian dung beetles. Journal of Tropical Ecology, 12: 449-460.

Horgan F.G. 2005. Effects of deforestation on diversity, biomass and function of dung beetles on the eastern slopes of the Peruvian Andes. Forest Ecology Management, 216: 117-133.

Horgan F.G. 2001. Burial of bovine dung by coprophagous beetles (Coleoptera: Scarabaeidae) from horse and cow grazing sites in El Salvador. European Journal of Soil Biology, 37: 103-111.

Janzen, D.H. 1983. Seasonal changes in abundance of large nocturnal dung beetles (Scarabaeidae) in a Costa Rican deciduous forest and adjacent horse pasture. Oikos, 41: 274-283.

Kindrall, O., Ahlen, I. 1992. Geometrical factors and meta popularion dynamics of the bush cricket, Merriop/eruhicolo rPhilippi (Orthoptera: 
Tettigoniidae). Conservation Biology, 6: 520-529.

Klein, B.C. 1989. Effect of forest fragmentation on dung and carrion beetle communities in central Amazonia. Ecology, 70: 1715-1725.

Larsen, T.H., Forsyth, A. 2005. Trap spacing and transect design for dung beetle biodiversity studies. Biotropica, 37: 322-325.

Larsen, T.H., Williams, N.M., Kremen, C. 2005. Extinction order and altered community structure rapidly disrupt ecosystem functioning. Ecology Letters, 8: 538-547.

Macdonald, D.W., Smith, I.T. 1990. Dispersal, dispersion and conservation in the agriculture ecosystems. Species dispersal in agricultural habitats, Bunce, R.G.F. and Howard, D.C. (eds.), p. 18-64, Bclhaven Press, London, UK.

Magurran, A.E. 2004. Measuring Biological Diversity, pp. 256, Blackwell Publishing, Oxford, UK.

Medley, K.E., Macdonnell, M.J., Pickett, S.T.A. 1995. Forest-landscape structure along an urban-to-rural gradient. Professional Geographer, 47: 159-168.

Nichols, L., Spector, S., Louzada, J., Larsen T.H., Amezquita S., Favila, M.E. 2008. Ecological functions and ecosystem services provided by Scarabaeinae dung beetles. Biological Conservation, 141: 1461-1474.

Nichols, E., Larsen, T., Spector, S., Davis, A.L., Escobar, F., Favila, M., Vulinec, K. 2007. Global dung beetle response to tropical forest modification and fragmentation: a quantitative literature review and meta-analysis. Biological Conservation, 137: 119.

Ott, J. 1995. Do dragonflies have a chance to survive in an industrialized country like Germany. In: Proceedittgs of Irelnrer -torionnlSyri posi troltntlte Conservation of Drogor, fliesartdrlleirHubirats, Corbet, P.S., Dunkle, S.W. and Ubukata, H., (eds.), pp. 28-44, Japanese Society for the Preservation of Birds, Kushiro, Japan.

Radtke, M.G., Carlton, C.E., Willianson, G.B. 2008. A dung beetle assemblage in an urban park in Lousiana. Southeastern Naturalist, 7: 101-110.

Sabu, T.K., Vinod, K.V., Vineesh, P.J. 2006. Guild structure, diversity and succession of dung beetles associated with Indian elephant dung in South Western Ghats forests. Journal of Insect Science, 6: 17 .
Sala, O.S., Chapin, III. F.S., Armesto, J., Berlow, E., Bloomfied, J., Dirzon, R., Huber-Sanwald, E., Hukennekel, Jackson, R., Kinzig, A., Leemans, R., Lodge, D.M., Mooney, D.A., Oesterheld, M., Poff, N., Sykes, M.T., Walker, B., Walker, M., Wall, D. 2000. Global biodiversity scenarios for the year 2100. Science, 287: 1770-1775.

Scheffler, P. 2005. Dung beetle (Coleoptera: Scarabaeidae) diversity and community structure across three disturbance regimes in eastern Amazonia. Journal of Tropical Ecology, 21: 9-19.

Shahabuddin, H.P., Manuwoto, S., Noerdjito, W.A., Tscharntke, T., Schulze, C.H. 2010. Diversity and body size of dung beetles attracted to different dung types along a tropical land-use gradient in Sulawesi, Indonesia. Journal of Tropical Ecology, 26: 53-65.

Shannon, C.E., Weaver, W. 1949. The Mathematical Theory of Communication. University of Illinois Press, Urbana.

Simpson, E. 1949. Measurement of diversity. Nature, 163-688.

Spector, S., Ayzama, S. 2003. Rapid turnover and edge effects in dung beetle assemblages (Scarabaeidae) at a Bolivian Neotropical Forest-Savanna Ecotone. Biotropica, 35: 394-404.

Spector, S. 2006. Scarabaeinae dung beetles (Coleoptera: Scarabaeidae: Scarabaeinae): an invertebrate focal taxon for biodiversity research and conservation. The Coleopterists Bulletin, 60: 71-83.

Vinod, K.V. 2009. Studies on the Systematics and Distribution of Dung Beetles (Coleoptera: Scarabaeinae) in the Forests and Agricultural Fields of Wayanad. Ph.D. Thesis, 214 pp., Forest Research Institute University, Dehradun.

Vinod, K.V., Sabu, T.K. 2007. Species composition and community structure of dung beetles attracted to dung of gaur and elephant in the moist forests of South western Ghats. Journal of Insect Science, 7: 6.

Vulinec, K. 2002. Dung beetle communities and seed dispersal in primary forest and disturbed land in Amazonia. Biotropics, 34: 297-309.

Wallace, M.G., Richardson, R.H. 2005. Observations of urban dung beetles utilizing dog feces (Coleoptera: Scarabaeidae). Coleoptera Bulletin, 59: 400-401. 